\title{
PENDEKATAN KONSELING LINTAS BUDAYA DALAM MENGATASI STIGMA NEGATIF TERHADAP KELOMPOK MINORITAS GENDER CALABAI
}

\author{
Rois Nafi'ul Umam \\ UIN Sunan Kalijaga Yogyakarta \\ 20200011107@student.uin-suka.ac.id
}

\section{Abstract}

The Calabai Gender Group as a group that has its own characteristics is vulnerable to negative stigma from the general public regarding the way they dress and behave. The purpose of this study is to provide a general description of the negative stigma and conditions directed at the Calabai gender group and to formulate the concept of cross-cultural counseling guidance as a solution in overcoming the problem of giving negative stigma to the group. The type of this research is basic/conceptual research with analytical descriptive method. Data collection techniques with literature study and interviews. The results showed that the negative stigma towards the calabai gender included satire, inappropriate words to invitations to exclude. The concept of cross-cultural counseling guidance to overcome this by holding group guidance with discussion techniques and using an emic approach that is looking for a middle way from cultural differences that exist between the Calabai gender group and the general public.

Key words: Cross Cultural Counseling, Negative Stigma, Gender Calabai

\section{Abstrak}

Kelompok Gender Calabai sebagai sebuah kelompok yang memiliki ciri khasnya tersendiri rentan menghadapi stigma negatif dari masyarakat umum berkenaan dengan cara berpakaian maupun berperilaku mereka. Tujuan dari penelitian ini adalah untuk gambaran umum mengenai kondisi dan stigma negatif yang diarahkan kepada kelompok gender calabai dan merumuskan konsep bimbingan konseling lintas budaya sebagai solusi dalam mengatasi masalah pemberian stigma negatif terhadap kelompok tersebut. Jenis dari penelitian ini adalah penelitian dasar/konseptual dengan metode deskriptif analitis. Teknik pengambilan data dengan studi kepustakaan dan wawancara. Hasil penelitian menunjukkan bahwa bentuk stigma negatif kepada gender calabai seperti sindiran, perkataan yang kurang pantas hingga ajakan untuk mengucilkan. Konsep bimbingan konseling lintas budaya untuk mengatasi hal ini dengan mengadakan bimbingan kelompok dengan teknik diskusi serta menggunakan pendekatan emik yakni mencari jalan tengah dari perbedaan budaya yang ada diantara kelompok gender calabai dan masyarakat umum.

Kata kunci: Konseling Lintas Budaya, Stigma Negatif, Gender Calabai 


\section{PENDAHULUAN}

Indonesia sebagai bangsa yang majemuk memiliki keragaman suku bangsa, bahasa, dan budaya. Keragaman tersebut termanifestasi dalam jumlah suku bangsa yang mencapai 1340 suku bangsa dan terdapat 718 bahasa daerah dalam bingkai negara kesatuan Republik Indonesia (Marta \& Rieuwpassa, 2018). Keberagaman suku dan budaya menjadi salah satu identitas pembeda Bangsa Indonesia dengan bangsa lainnya, mengingat tidak semua bangsa yang ada di dunia memiliki keragaman suku dan budaya seperti di Indonesia. Meskipun masyarakat indonesia memiliki berbagai latar belakang suku bangsa yang berbeda-beda, mereka tetap dapat bersatu padu membangun dan menjaga keutuhan negara dengan berpegangan pada prinsip Bhinneka Tunggal Ika atau berbeda-beda tapi tetap satu (Lestari, 2015).

Kebudayaan yang ada di Indonesia tidak hanya berkenaan dengan bahasa, tarian,makanan, rumah adat dan lain sebagainya, akan tetapi juga berhubungan dengan konstruksi gender manusia. Pada masyarakat Suku Bugis, konstruksi gender manusia tidak hanya terbatas pada laki-laki dan perempuan, akan tetapi juga gender calabai, calalai dan bissu (Purwaningsih, 2017). Calabai merupakan individu yang secara fisik adalah seorang laki-laki akan tetapi berperilaku layaknya seorang perempuan. Begitu pula dengan calalai yaitu individu yang secara fisik adalah perempuan akan tetapi berperilaku layaknya seperti lakilaki. Adapun yang dimaksud dengan bissu adalah pendeta suku Bugis yang secara fisik laki-laki dan berpenampilan layaknya perempuan (Purwaningsih, 2017). Menurut Graham Davies dalam Triadnyani (2018), konstruksi gender pada suku Bugis yang menghendaki adanya laki-laki yang berpenampilan layaknya perempuan dan perempuan yang berpenampilan layaknya laki-laki serupa dengan konsep konstruksi gender pada masyarakat barat yang menghendaki adanya kelompok transgender yaitu individu yang merasa bahwa identitas gendernya saat ini berbeda dengan jenis kelamin yang dibawa saat lahir. Secara konsep keduanya kurang lebih sama yaitu menghendaki laki-laki yang hendak berpenampilan seperti perempuan dan perempuan yang hendak berpenampilan seperti seorang lelaki.

Manusia dengan gender calabai secara tampilan dan perilaku akan terlihat seperti seorang perempuan. Individu dengan gender calabai dapat mengenakan gaun, memanjangkan rambut, memakai rok mini dan berperilaku feminin. Gender calabai pada masyarakat suku Bugis secara hukum adat diakui kedudukannya dalam kehidupan masyarakat, sehingga masyarakat pada suku tersebut telah terbiasa dan tidak merasa aneh dengan keberadaan individu gender calabai (Rokhmansyah, Hanum, \& Dahlan, 2018). Bagi kalangan masyarakat luar, gender calabai dianggap sebagai hal yang menyalahi kodratnya sebagai seorang manusia yang telah diciptakan dengan jenis kelamin 
yang telah ditentukan sang pencipta. Oleh karenanya tidak semua suku/daerah lain dapat menerima keberadaan gender calabai dengan baik (Ismoyo, 2020). Nilai-nilai masyarakat yang bersumber dari ajaran agama yang tidak menghendaki manusia yang berperilaku berbeda dari jenis kelaminnya, menjadikan gender calabai tidak semuanya dapat diterima di wilayah tertentu di negara ini.

Gender calabai dapat dikategorikan sebagai kelompok minoritas mengingat populasinya yang tidak banyak di kalangan masyarakat. Populasi individu dengan gender calabai saat ini berjumlah 200 orang dan mereka hidup dalam kelompok masyarakat yang satu identitas dengan mereka yakni kelompok masyarakat suku Bugis (Nurohim, 2018). Kelompok ini sebagai sebuah kelompok minoritas yang diakui oleh Komisi Nasional Hak Asasi Manusia (KOMNAS HAM) dan dikategorikan dalam kelompok minoritas gender-seksualitas. Dalam kehidupannya sehari-hari, gender calabai rentan menghadapi stigma negatif yang diberikan oleh masyarakat umum kepada mereka. Stigma negatif tersebut didasarkan pada perbedaan pandangan mengenai jenis kelamin dan gender sehingga masyarakat berasumsi bahwa yang mereka lakukan sebagai perilaku menyalahi kodrat yang telah ditetapkan oleh Tuhan (Nurohim, 2018).

Stigma negatif terhadap kelompok gender calabai bukan merupakan hal yang baru terjadi dan telah diangkat dalam beberapa penelitian terdahulu. Penelitian yang dilakukan oleh Muhammad Dani menunjukkan bahwa kelompok gender calabai kurang mendapatkan peran penting dalam kehidupan masyarakat dan cenderung diabaikan oleh lingkungan sekitar. Hal ini didasarkan oleh pandangan masyarakat yang menilai bahwa tampilan fisik maupun perilaku yang ditunjukkan oleh kelompok ini berbeda dengan masyarakat pada umumnya (Dani, 2016). Hal ini didukung dengan penelitian yang dilakukan oleh Fitriani yang menyatakan bahwa stigma negatif yang diarahkan terhadap kelompok gender calabai didasarkan pada asumsi masyarakat awam mengenai pribadi kelompok gender calabai ini (Fitriani, 2018). Adapun dalam realita di lapangan yang ditemukan oleh peneliti melalui hasil wawancara dengan salah satu anggota kelompok gender calabai tersebut yang menyatakan bahwa mereka menghadapi permasalahan penyesuaian diri dengan lingkungan sekitarnya yang ditambah dengan pandangan negatif atau stigma berdasarkan apa yang dilihat oleh masyarakat dari tampilan secara fisik mereka (Karaeng, 2021:Wawancara). Stigma negatif sebagai sebuah permasalahan yang terjadi secara nyata dan dapat berdampak terhadap kondisi psikologis kelompok gender calabai itu sendiri seperti tidak percaya diri, merasa rendah diri dan adanya konsep diri yang negatif. 
Dalam upaya mengatasi stigma negatif kepada kelompok ini, penulis mengajukan konsep pendekatan konseling lintas budaya sebagai solusi atas masalah tersebut. Konseling lintas budaya merupakan hubungan konseling yang melibatkan peserta dengan etnik/latar belakang yang berbeda, atau dari kelompok minoritas (Syahril, 2018). Konseling lintas budaya juga dapat mengakomodir konselor dan klien yang memiliki latar belakang atau budaya yang berbeda. Pendekatan konseling lintas budaya dalam hal ini akan mempertemukan konselor, kelompok gender calabai dan perwakilan kelompok masyarakat yang berbeda cara pandang dengan kelompok gender calabai. Konseling lintas budaya ini memiliki tujuan agar masyarakat umum dapat menerima keberadaan kelompok gender calabai dan tidak lagi menyebarkan stigma negatif atas perilaku dan penampilan yang mereka tunjukkan. Ketika hal tersebut tercapai maka kehidupan antar kelompok yang berbeda ini dapat berjalan beriringan dan tidak saling memberi pandangan/stigma negatif.

Dari latar belakang diatas, maka peneliti kemudian merasa perlu untuk melakukan kajian dan membuat sebuah konsep sederhana mengenai pendekatan konseling lintas budaya dalam mengatasi stigma negatif terhadap kelompok minoritas gender calabai. Tujuan dari penulisan artikel ini yaitu memberikan gambaran kepada pembaca mengenai konsep konseling lintas budaya dalam hal mengatasi stigma negatif bagi kelompok gender calabai.

\section{KAJIAN PUSTAKA}

\section{Teori Tentang Stigma}

Kata stigma berasal dari bahasa Yunani yang berarti tanda keburukan atau hal yang memalukan. Adapun dalam kamus besar bahasa Indonesia (KBBI), stigma diartikan sebagai sebuah ciri negatif yang menempel pada diri individu yang terbentuk dari lingkungan sekitarnya. Menurut para ahli, yakni Lacko dan Gronholm, stigma pada umumnya berhubungan dengan kehidupan sosial di masyarakat yang mana salah seorang atau kelompok yang dipandang berbeda, baik secara fisik maupun non fisik akan diberi label atau tanda yang bersifat negatif. Seseorang/sekelompok orang yang mendapatkan stigma negatif dari lingkungan masyarakat akan merasa terasingkan/terkucilkan diakibatkan penerimaan yang kurang baik dari masyarakat sekitar.

Stigma terhadap individu/kelompok yang terjadi di masyarakat umumnya mengarah pada orang-orang yang memiliki aspek fisik dan non fisik yang berbeda dari masyarakat sekitar. Aspek fisik dalam hal ini meliputi kondisi fisik individu yang memiliki kekurangan atau berbeda dengan kondisi fisik orang lain pada umumnya, contohnya dalam hal ini yaitu penyandang

disabilitas fisik dan sensorik yang memiliki keterbatasan dalam hal 
kemampuan fisik atau penggunaan alat indera yang dapat menghambatnya untuk beraktivitas sehari-hari. Kondisi kekurangan pada penyandang disabilitas tersebut yang kemudian dinilai oleh masyarakat sekitar sebagai sebuah hambatan/keterbatasan yang pada akhirnya masyarakat memberikan stigma negatif kepada mereka. Adapun aspek non fisik dalam hal ini yaitu perilaku individu dan latar belakang identitasnya, baik itu suku, agama maupun ras. Individu yang memiliki perilaku yang dipandang buruk atau berbeda dari masyarakat sekitar akan mendapatkan stigma negatif, begitu pula jika individu memiliki latar belakang yang berbeda dari masyarakat sekitar, maka ia juga rentan mendapatkan stigma negatif.

Pemberian stigma terhadap individu/kelompok tertentu secara umum terbentuk dari berbagai faktor yang meliputi ketakutan dan sikap acuh tak acuh yang ada di lingkungan sosialnya. Masyarakat pada umumnya akan memiliki sikap takut atau khawatir apabila ada seseorang/sekelompok orang yang memiliki sikap dan perilaku yang berbeda. Perbedaan tersebut dikhawatirkan dapat mempengaruhi atau berdampak pada masyarakat di tempat tersebut. Oleh karenanya masyarakat memunculkan stigma negatif untuk membatasi hubungan sosial antara kelompok mereka dengan individu/kelompok yang mendapatkan stigma. Faktor berikutnya adalah sikap acuh tak acuh yang diperlihatkan oleh kelompok masyarakat terhadap individu/kelompok yang dipandang memiliki kekurangan atau tidak dapat berkontribusi di kehidupan masyarakat. Sikap mengacuhkan ini didasarkan pada pemikiran atau pandangan masyarakat bahwa individu/kelompok yang mendapatkan stigma sulit untuk diajak berkontribusi dalam kehidupan sosial bermasyarakat dan oleh karenanya mereka diberi stigma negatif oleh lingkungan sekitarnya.

Stigma negatif yang diarahkan kepada individu/kelompok tertentu dapat menimbulkan dampak negatif bagi yang bersangkutan. Dampak dari pemberian stigma tersebut berkaitan dengan kondisi psikis korbannya, yakni korban pemberian stigma tersebut akan merasa takut, khawatir, memiliki konsep diri negatif serta tidak percaya diri. Rasa takut dan khawatir akan muncul ketika individu berada dalam kondisi tertekan dalam hal ini, stigma negatif yang diterima mereka secara terus-menerus dapat menyebabkan tekanan dalam diri mereka yang bermuara pada sikap takut dan khawatir. Stigma juga berhubungan dengan konsep diri dan kepercayaan diri individu dimana ketika individu tersebut mendapatkan stigma negatif dari masyarakat sekitar, ia akan memberikan penilaian negatif terhadap dirinya sendiri dan pada akhirnya membuatnya tidak percaya diri untuk bergabung dalam kehidupan sosial masyarakat. 


\section{Teori Bimbingan Konseling Lintas Budaya}

Secara garis besar, bimbingan konseling lintas budaya merupakan jenis layanan bimbingan konseling yang mengakomodir perbedaan-perbedaan budaya yang ada dunia dalam prosesnya. Budaya yang menjadi dasar atau ciri khas individu untuk berpikir/berperilaku akan memberikan pengaruh terhadap proses bimbingan konseling yang dijalani oleh klien dan konselor (Suci Prasasti, 2018). Menurut seorang ahli yakni Von-Trees (Nuzliah, 2016), bimbingan konseling lintas budaya adalah kegiatan bimbingan konseling yang mana antara konselor dan konseli memiliki perbedaan budaya dikarenakan berada dalam lingkungan sosial yang berbeda. Dalam pendapat lain yang dikemukakan oleh Pederson (Syahril, 2018), dijelaskan bahwa bimbingan konseling lintas budaya merupakan konseling yang melibatkan konselor dan klien yang berbeda secara budaya dan rentan mengalami bias-bias budaya yang menyebabkan konseling tidak berjalan dengan baik. Biasa budaya terjadi ketika antara konselor dan klien tidak saling memahami budayanya dan menggunakan perspektif budayanya sendiri.

Bimbingan konseling lintas budaya yang dilakukan oleh konselor dan konseli didasarkan pada tujuan untuk membantu pengembangan diri konseli dan membantu penyelesaian masalah konseli. Menurut Nuzliah (Nuzliah, 2016), tujuan dari bimbingan konseling lintas budaya adalah membantu individu dalam mengembangkan perilaku positif dalam keadaan apapun, membantu individu untuk dapat berperilaku baik dan dapat hidup bersama dalam masyarakat serta dapat memecahkan masalah yang bersumber dari keberagaman budaya yang ada di masyarakat.

Dalam mencapai tujuan dari bimbingan konseling lintas budaya, konselor perlu menetapkan dan menggunakan pendekatan yang tepat. Pendekatan dalam hal ini sebagai sebuah landasan yang kemudian dijabarkan dalam bentuk pedoman-pedoman teknis pelaksanaan bimbingan konseling lintas budaya. Menurut Nuzliah (Nuzliah, 2016), pendekatan dalam bimbingan konseling lintas budaya terbagi menjadi 3 jenis, yakni pendekatan universal, pendekatan emik dan pendekatan inklusif. Pendekatan universal yakni pendekatan yang berfokus pada universalitas dari sebuah budaya sehingga sebuah budaya dapat diterima oleh semua kalangan. Pendekatan emik yaitu pendekatan yang memperhatikan ciri khas dari budaya yang ada dan menyesuaikan dengan kebutuhan saat proses bimbingan konseling. Pendekatan yang terakhir yaitu pendekatan inklusif yakni pendekatan yang menekankan keterlibatan konselor dalam proses bimbingan konseling yang sedang berlangsung.

Dalam menjalankan kegiatan bimbingan konseling lintas budaya, segala kemungkinan dapat terjadi, termasuk potensi munculnya hambatan di dalamnya. Hambatan dalam proses bimbingan konseling lintas budaya seperti 
bahasa, nilai dan streotipe (Suci Prasasti, 2018). Bahasa sebagai media komunikasi antar personal dapat menjadi penghambat apabila salah satu pihak tidak memahami bahasa yang digunakan oleh pihak lain dalam proses bimbingan konseling lintas budaya tersebut. Nilai yang menjadi penghambat dalam bimbingan konseling lintas budaya yaitu memaksakan nilai diri terhadap orang lain dan memaksakan nilai kelompok mayoritas kepada kelompok minoritas. Bentuk pemaksaan terhadap nilai tertentu yang bagi kalangan tertentu bertentangan dengan nilai yang dianutnya bertentangan dengan prinsip bimbingan konseling lintas budaya yang menghargai setiap budaya yang ada. Penghambat yang berikutnya yaitu streotipe yang berasal dari prasangka-prasangka negatif atau kebencian terhadap individu/kelompok tertentu.

\section{METODE}

Jenis dari penelitian ini adalah penelitian dasar/konseptual yakni untuk mengembangkan keilmuan atau teori yang telah ada. Dalam hal ini, penelitian dilakukan untuk mengembangkan konsep bimbingan konseling lintas budaya untuk menjadi sebuah solusi bagi permasalahan stigma negatif bagi kelompok gender calabai. Metode yang digunakan dalam penelitian ini adalah deskriptif analitis yaitu memberikan gambaran tentang suatu kelompok masyarakat dan dianalisa menggunakan teori yang berhubungan dengan objek kajian (Salim \& Syahrum, 2012). Pengumpulan data dalam penelitian ini menggunakan dua teknik yang berbeda yakni kepustakaan dan wawancara. Kepustakaan dimaksudkan untuk memperoleh informasi yang berkaitan dengan topik penelitian yang diperoleh dari buku-buku referensi dan wawancara dimaksudkan untuk memperoleh data pendukung dan gambaran mengenai realita di lapangan (Salim \& Syahrum, 2012). Teknik analisis data menggunakan model miles dan huberman yakni reduksi data, penyajian data dan diakhiri dengan menarik kesimpulan (Gulo, 2014).

\section{HASIL DAN PEMBAHASAN}

\section{Kelompok Minoritas: Gender Calabai dan Stigma Negatif dari Masyarakat}

Kelompok minoritas adalah kelompok masyarakat yang memiliki populasi yang kecil dan berada dalam posisi yang tidak dominan. Menurut Komisi Nasional untuk Hak Asasi Manusia (Komnas Ham) Republik Indonesia, kelompok minoritas di Indonesia terbagi menjadi beberapa kategori seperti, kelompok minoritas agama, minoritas gender-seksualitas, minoritas penyandang disabilitas, minoritas ras dan minoritas etnis (Fadhli, 2014). Sebagai sebuah kelompok minoritas, keberadaan dan peran mereka dalam 
kehidupan masyarakat tidak sebesar kelompok lain yang memiliki populasi yang lebih besar atau dominan dalam segala aspek, sehingga mereka rentan untuk diperlakukan tidak adil, mengalami hambatan untuk berkembang serta tidak dapat memperoleh hak atas kehidupan yang dijamin bagi setiap warga negara didalamnya (Risdianto, 2017). Selain menghadapi hambatan dalam pemenuhan hak dan partisipasi dalam bernegara, kelompok minoritas juga rentan menjadi korban perilaku diskriminasi, pemberian streotipe negatif dan ancaman terhadap kelangsungan hidup mereka yang dilakukan oleh kalangan masyarakat yang dominan melalui perilaku-perilaku yang bertentangan dengan prinsip keadilan dan norma-norma yang berlaku (Abdurrahman, Al-Banjari, \& Muradi, 2019).

Salah satu bagian dari kelompok minoritas adalah kelompok minoritas gender-seksualitas. Dalam kelompok ini, konsep gender dan seksualitas yang dianut/diakuinya dapat berbeda dari konsep gender/seksualitas yang berlaku pada masyarakat secara umum. Pada masyarakat umum, konsep gender yang berlaku adalah laki-laki yang berpenampilan dan berperilaku maskulin dan perempuan yang berpenampilan dan berperilaku feminim. Adapun konsep seksualitas dalam pandangan masyarakat adalah hubungan seksual yang dilakukan individu harus didasarkan perbedaan jenis kelamin yaitu laki-laki dan perempuan serta terikat dalam ikatan yang sah, baik dalam agama maupun aturan negara (Puspitasari, 2019). Bagi kelompok minoritas tersebut, laki-laki yang maskulin dan perempuan bukan menjadi keharusan atau berlaku mutlak terhadap setiap manusia. Ditambahkannya bahwasanya tidak menutup kemungkinan laki-laki akan berperilaku dan berpenampilan seperti perempuan dan perempuan yang berperilaku dan berpenampilan seperti laki-laki dikarenakan adanya faktor internal dan eksternal yang berpengaruh terhadap hal tersebut (Widiastuti, 2017). Faktor internal yang dimaksud adalah gen dari orang tua dan faktor eksternal meliputi lingkungan sekitarnya dan didikan dari orang tuanya. Adapun konsep seksualitas bagi kelompok tersebut tidak terbatas hanya untuk pasangan yang berbeda jenis kelamin, akan tetapi pasangan sesama jenis kelamin juga memperoleh kesempatan yang sama untuk melakukan hubungan seksual yang didasarkan atas hak asasi manusia. (Widiastuti, 2017)

Contoh dari kelompok minoritas gender di Indonesia adalah kelompok gender Calabai. Kelompok ini merupakan bagian dari konstruksi gender yang ada pada masyarakat suku Bugis selain laki-laki, perempuan calalai dan bissu. Calabai merupakan individu yang terlahir sebagai laki-laki, yang kemudian mengambil peran, berperilaku dan berpenampilan layaknya seorang perempuan dengan memanjangkan rambut mereka. Mereka memiliki perilaku yang feminim dan sering menggunakan pakaian yang berafiliasi dengan 
perempuan, seperti gaun, rok mini dan baju-baju yang menampilkan gambar/tulisan tentang perempuan (Purwaningsih, 2017). Dalam kesehariannya, banyak calabai yang bekerja pada salon kecantikan dan menjadi penata rias untuk acara pernikahan. Kelompok calabai bagi masyarakat Bugis merupakan hal yang biasa dan memiliki kedudukan yang sama dengan masyarakat umum. Hal ini akan berbeda jika mereka berada diluar lingkungan mereka atau dipandang oleh masyarakat umum (Purwaningsih, 2017).

Karena memiliki ciri fisik dan perilaku yang berbeda dari masyarakat umum, kelompok gender calabai rentan menghadapi stigma negatif dari masyarakat. Stigma tersebut yakni pemberian label atau cap negatif terhadap kelompok minoritas gender calabai ini. Pemberian stigma tersebut didasarkan pada pandangan/penilaian masyarakat sekitar terhadap cara berpakaian dan berperilaku mereka (Novri, 2014). Secara umum bentuk stigma negatif yang diarahkan kepada mereka yakni sindiran atau ucapan seperti menyalahi kodrat sebagai manusia, kurang pantas hingga ada ajakan untuk mengucilkan kelompok mereka (Novri, 2014). Perilaku memberikan stigma negatif dan pengucilan terhadap kelompok ini berdampak pada konsep diri dan kepercayaan diri mereka meskipun mereka tetap berusaha mempertahankan identitas yang ada pada diri mereka.

\section{Konseling Lintas Budaya: Upaya dalam Mengatasi Stigma Negatif Terhadap Kelompok Minoritas Gender Calabai}

Konseling lintas budaya adalah proses konseling yang melibatkan konselor dan konseli yang memiliki perbedaan budaya dan proses konseling tersebut dilakukan dengan memperhatikan budaya subjek yang terlibat pada proses konseling (Syahril, 2018). Dalam konseling lintas budaya, konselor dengan konseli memiliki dasar budayanya masing-masing dan karena itu dapat menjadikannya sebagai bias budaya dalam proses konseling yang dapat menghambat efektivitas dari konseling yang sedang berjalan. Dalam hal mengatasi bias budaya tersebut maka konselor perlu untuk melepaskan diri dari bias budaya, menghargai dan mengapresiasi atas budaya yang dimiliki oleh konseli (Suwarni, 2016). Menurut seorang ahli yaitu Atkinson, konseling lintas budaya dapat terjadi jika konselor dan konseli berbeda etnik atau jika memiliki kesamaan etnik maka dapat ditinjau dari variabel lain seperti orientasi seksual, kondisi sosial, ekonomi dan usia (Suwarni, 2016).

Konseling lintas budaya ditujukan untuk membantu klien dalam mengembangkan diri atau menyelesaikan masalah yang dihadapinya dengan menggunakan pendekatan budaya yang dimilikinya. Hal ini dikarenakan setiap masalah yang dihadapi klien tidak semua dapat ditangani melalui pendekatan 
secara ilmiah dan memungkinkan untuk alternatif penyelesaiannya melalui pendekatan kebudayaan yang dimiliki oleh klien (Suci Prasasti, 2018). Selain itu, melalui pendekatan konseling lintas budaya ini, klien dapat mendalami budaya dari identitas dirinya, dan mengetahui budaya serta adat istiadat yang dianut oleh individu/kelompok lainnya. Melalui pendekatan konseling lintas budaya, individu diharapkan dapat menggunakan aspek budaya dalam penyelesaian masalah yang ada dalam kehidupannya (Suci Prasasti, 2018).

Indonesia sebagai salah satu negara yang memiliki keragaman budaya dapat menjadi contoh penerapan dari konseling lintas budaya. Hal ini dikarenakan masing-masing suku yang memiliki budaya berbeda akan memiliki cara pandang yang berbeda pula dalam menghadapi sebuah masalah (Masturi, 2015). Oleh karenanya, pendekatan konseling lintas budaya menjadi jalan bagi konselor dan konseli yang memiliki latar belakang budaya yang berbeda untuk bersama-sama mencari alternatif penyelesaian masalah dengan menggunakan pendekatan kebudayaan yang dimiliki oleh klien (Masturi, 2015). Suku Bugis sebagai bagian dari keragaman suku bangsa di Indonesia memiliki berbagai budaya yang ada didalamnya, termasuk diantaranya budaya konstruksi gender. Dalam konstruksi gender pada masyarakat suku Bugis, gender manusia tidak hanya terbatas pada laki-laki dan perempuan, akan tetapi juga calabai, calalai dan bissu. Calabai merupakan seorang laki-laki yang berperilaku seperti perempuan dan calalai adalah perempuan yang berperilaku dan berpenampilan seperti laki-laki. Adapun yang dimaksud dengan bissu yaitu pendeta pada masyarakat Bugis yang memiliki gender campuran yakni laki-laki dan perempuan (Triadnyani, 2018). Pada masyarakat Bugis, gender calabai memiliki tempat dan kedudukan yang sama dengan gender pada umumnya yakni laki-laki dan perempuan. Akan tetapi konstruksi gender calabai ini dapat bertentangan dengan nilai-nilai yang dianut oleh masyarakat lain diluar suku Bugis, sehingga dapat menimbulkan pandangan/persepsi negatif terhadap mereka (Triadnyani, 2018). Persepsi negatif masyarakat umum kepada mereka kemudian ditunjukkan dalam bentuk ucapan maupun perbuatan yang mengarahkan orang lain untuk memberi cap/stigma negatif pada mereka. Mereka dipandang menyalahi kodrat dari Tuhan yang telah menciptakannya, berperilaku aneh dan tidak sesuai dengan ketentuan agama dan budaya masyarakat (Ismoyo, 2020). Hal ini menunjukkan bahwa perbedaan budaya yang ada dalam masyarakat dapat menimbulkan perbedaan pandangan yang dapat berujung pada pemberian cap/stigma pada kelompok yang dianggap bertentangan. Hal ini pada dasarnya tidak harus terjadi jika masing-masing pihak dapat mengenali budaya luar dan tidak membuat asumsi pribadi yang kemudian dikembangkan menjadi pandangan kelompok masyarakat terhadap kelompok yang lainnya. 
Permasalahan perbedaan budaya yang didalamnya terselip pemberian stigma negatif terhadap kelompok tertentu perlu untuk ditangani oleh pihakpihak yang dapat membantu untuk menjembatani akomodasi dan akulturasi antar budaya sekaligus mencari solusi atas permasalahan yang ada. Dalam hal ini penulis mengajukan konsep pendekatan bimbingan konseling lintas budaya dalam rangka mengatasi permasalahan ini. Bimbingan konseling lintas budaya yang difasilitasi oleh konselor yang memahami masing-masing budaya yang ada dan tidak melakukan bias-bias budaya. Tujuan dari program bimbingan konseling lintas budaya ini yaitu untuk membantu konseli yang terdiri dari dua pihak yakni kelompok gender calabai dan perwakilan kelompok masyarakat yang ada untuk membangun sikap saling menerima dan menghargai sekaligus membuka ruang interaksi dan diskusi untuk mengatasi permasalahan yang ada akibat perbedaan budaya tersebut.

Secara teknis, bimbingan konseling lintas budaya dalam kasus ini dapat dilakukan secara berkelompok dengan menggunakan teknik diskusi. Teknik diskusi dilakukan dengan mempersilahkan masing-masing anggota kelompok untuk menyampaikan pendapatnya yang kemudian didiskusikan bersamasama untuk mencapai hasil diskusi yang dapat diterima bersama. Adapun pendekatan yang digunakan dalam kasus ini dalam tinjauan bimbingan konseling lintas budaya yakni pendekatan universal yakni pendekatan emik dimana masing-masing kelompok yang memiliki budaya yang berbeda dapat menyesuaikan diri pada saat proses bimbingan konseling berlangsung dan dapat menjadi titik temu antar dua budaya yang berbeda. Dalam proses bimbingan konseling lintas budaya ini setiap anggota kelompok diharapkan dapat menahan diri untuk tidak memaksakan kehendak pribadi/kelompoknya saja dan melontarkan ucapan-ucapan yang mengarah pada streotipe. Melalui bimbingan konseling lintas budaya ini, diharapkan dapat menjadi jalan dalam mengatasi pemberian stigma negatif terhadap kelompok minoritas gender calabai.

\section{KESIMPULAN}

Gender calabai merupakan bagian dari konstruksi gender pada suku Bugis dimana individu yang berjenis kelamin laki-laki akan berperilaku dan berpenampilan layaknya seorang perempuan. Populasi gender calabai di Indonesia yang jumlahnya sangat sedikit dapat dikategorikan menjadi kelompok minoritas dari aspek gender seksualitas. Dalam kehidupan seharihari mereka rentan untuk mendapatkan stigma negatif dari masyarakat umum karena perilaku dan penampilan mereka yang bertentangan dengan nilai moral yang umumnya diakui di masyarakat. Untuk mengatasi masalah stigma negatif tersebut, intervensi yang dapat digunakan yakni bimbingan konseling lintas 
budaya. Dalam kegiatan tersebut kelompok gender calabai dan masyarakat umum dapat saling mengenal dan memahami budayanya, mengatasi segala bentuk pemberian stigma negatif atau streotipe, dan mengatasi permasalahan yang ada diantara kelompok tersebut. Secara teknis bimbingam konseling lintas budaya dijalankan secara berkelompok dengan menggunakan teknik diskusi serta menggunakan pendekatan emik dalam tinjauan bimbingan konseling lintas budaya.

\section{DAFTAR PUSTAKA}

Abdurrahman, A., Al-Banjari, M. H., \& Muradi, M. (2019). Terpilihnya Figur Minoritas Dalam Masyarakat Majemuk Beloto Kabupaten Flores Timur: Tinjauan Perspektif Teori Pengaruh Minoritas Dan Teori Kontak. AlIjtima i: International Journal of Government and Social Science, 4(2), 145. https://doi.org/10.22373/jai.v4i2.454

Dani, M. (2016). Calabai: Struktur Gender Suku Bugis. Jurnal Ilmu Sosial Budaya, $5(2), 8$.

Fadhli, Y. Z. (2014). Kedudukan Kelompok Minoritas Dalam Perspektif Ham Dan Perlindungan Hukumnya Di Indonesia. Jurnal Konstitusi, 11(2), 360. https://doi.org/10.31078/jk

Fitriani. (2018). Calabai dan Penerimaan Masyarakat. Journal Of Social Culture, $10(5), 37$.

Gulo, W. (2014). Metodologi Penelitian (8th ed.; Dartono, ed.). Jakarta: Gramedia Widiasarana Indonesia.

Ismoyo, P. J. (2020). Decolonizing Gender Identities in Indonesia: A Study of Bissu' The Trans-Religious Leader's In Bugis People. Paradigma: Jurnal Kajian Budaya, 10(3), 283. https://doi.org/10.17510/paradigma.v10i3.404

Lestari, G. (2015). Bhinnekha Tunggal Ika: Khasanah Multikultural Indonesia di Tengah Kehidupan Sara. Jurnal Pendidikan Pancasila Dan Kewarganegaraan, 28(1), 31-37.

Marta, R. F., \& Rieuwpassa, J. S. (2018). Identifikasi Nilai Kemajemukan Indonesia Sebagai Identitas Bangsa dalam Iklan Mixagrip Versi Keragaman Budaya. Jurnal Kajian Komunikasi, 6(1), 37. https://doi.org/10.24198/jkk.v6i1.15416

Masturi, M. (2015). Counselor Encapsulation: Sebuah Tantangan Dalam Pelayanan Konseling Lintas Budaya. Jurnal Konseling Gusjigang, 1(2), 6. 
https://doi.org/10.24176/jkg.v1i2.407

Novri, M. (2014). Gender Calabai dan Stigma Negatifnya. Jurnal Ilmu Budaya, $3(2), 18$.

Nurohim, S. (2018). Identitas dan Peran Gender pada masyarakat Suku Bugis. Sosietas, 8(1), 4460.

Nuzliah. (2016). Counseling Multikultural. JURNAL EDUKASI: Jurnal Bimbingan Konseling, 2(2), 205. https://doi.org/10.22373/je.v2i2.816

Purwaningsih, P. (2017). Transgender Dalam Novel Calabai Karya Pepi Al Bayqunie: Kajian Identitas. Aksara, 29(2), 185. https://doi.org/10.29255/aksara.v29i2.74.183-196

Puspitasari, I. C. (2019). Opresi Kelompok Minoritas: Persekusi dan Diskriminasi LGBT di Indonesia. Jurnal Studi Gender Dan Islam Serta Perilindungan Anak, 8, 83-102.

Risdianto, D. (2017). Perlindungan Terhadap Kelompok Minoritas di Indonesia dalam Mewujudkan Keadilan dan Persamaan di Hadapan Hukum. Jurnal Rechts Vinding: Media Pembinaan Hukum Nasional, 6(1), 128. https://doi.org/10.33331/rechtsvinding.v6i1.120

Rokhmansyah, A., Hanum, I. S., \& Dahlan, D. (2018). Calabai Dan Bissu Suku Bugis: Representasi Gender Dalam Novel Calabai Karya Pepi Al-Bayqunie. CaLLS (Journal of Culture, Arts, Literature, and Linguistics), 4(2), 93. https://doi.org/10.30872/calls.v4i2.1645

Salim, \& Syahrum. (2012). Metodologi Penelitian Kualitatif (Haidir, ed.). Bandung: citapustaka Media.

Suci Prasasti. (2018). Konseling Lintas Budaya. Jurnal Ilmiah Konseling, 18(2), 12.

Suwarni, S. (2016). Memahami Perbedaan Budaya sebagai Sarana Konseling Lintas Budaya. KONSELING RELIGI Jurnal Bimbingan Konseling Islam, 7(1), 119. https://doi.org/10.21043/kr.v7i1.1697

Syahril. (2018). Konseling Lintas Budaya dalam Perspektif Budaya Indonesia. Jurnal Al-Taujih, 4(1), 78.

Triadnyani, I. G. A. A. M. (2018). From Gender Identity Oppression to Power Reversal in the Novel Calabai. Jurnal Humaniora, 30(2), 170. https://doi.org/10.22146/jh.v30i2.28171 
Widiastuti, R. K. (2017). Problem-Problem Minoritas Transgender dalam Kehidupan Sosial Beragama. Jurnal Sosiologi Agama, 10(2), 135. https://doi.org/10.14421/jsa.2016.1002-06 